\title{
Pengaruh Earning Per Share Dan Dividen Per Share Terhadap Harga Saham Perusahaan Sektor Properti, Real Estate Dan Konstruksi Yang Terdaftar Di Bursa Efek Indonesia
}

\author{
Desy Sulistiawati , Herman Sjahruddin, Bungatang Tahir \\ Sekolah Tinggi Ilmu Ekonomi Makassar Bongaya, Sulawesi Selatan \\ Email : desysulistiawati27@gmail.com
}

\begin{abstract}
Abstrak
Studi ini menguji dampak laba per saham (earning per share) dan dividen per saham terhadap harga saham sektor properti, real estate dan jasa konstruksi di Bursa Efek Indonesia. 82 perusahaan digunakan sebagai populasi. Sampel mengadopsi metode purpose sampling, dengan 16 perusahaan sebagai sampel (66 perusahaan, yang tidak memenuhi standar, dan data dianggap tidak dapat digunakan). Regresi linier berganda dengan bantuan SPSS v. 25 merupakan peralatan penelitian, yang hasilnya mebunjukkan bahwa laba per saham (earning per share) berkontribusi positif signifikan sedangkan dividen per saham (dividen per share) berkontribusi positif tidak signifikan terhadap harga saham penutupan (closing price).
\end{abstract}

Kata kunci: Laba per saham, Dividen per saham, Harga Saham

\begin{abstract}
This study aims to examine the impact of earnings per share and dividend per share on the stock prices of real estate and construction services sub-sector companies listed on the Indonesia Stock Exchange. The study population was 82 emiten. The sample adopted the purpose sampling method, with 16 emiten as samples (66 which did not meet the standards, and the data were considered to be inappropriate). The analytical tool used is multiple linear regression analysis with the help of SPSS v.25. The results showed that earnings per share had a significant positive effect while dividends per share had a insignificant effect on stock prices.
\end{abstract}

Keywords : Earning, Dividen Per Share, Closing Price

\section{PENDAHULUAN}

Kebutuhan masyarakat dalam pengadaan properti merupakan kebutuhan mendasar. Permintaan yang tinggi dalam industri ini menjadi salah satu alasan persaingan ketat dalam bisnis real estate.

Kinerja keuangan industri real estate dipengaruhi oleh faktor eksternal seperti peraturan pemerintah, tingkat inflasi dan serta faktor internal seperti kepercayaan masyarakat dan manajemen keuangan perusahaan. Industri ini aktivitas usahanya bergerak dalam pembangunan apartemen, rumah, kantor, real estate dan jasa konstruksi lainnya. Industri ini biasanya dipilih sebagai salah satu alat bisnis yang dapat membawa banyak keuntungan bagi investor, dan merupakan investasi jangka panjang yang menarik bagi investor karena tingginya tingkat permintaan masyarakat.

Pada tahun 2019 terdapat 82 emiten di subsektor ini yang sahamnya diperdagangkan pada BEI (Nirmalasari L., 2018). Kondisi keuangan pada sub-sektor ini merupakan salah satu kegiatan bisnis yang paling rentan dalam industri makro serta memiliki resistensi yang tinggi pada suku bunga, tingkat inflasi,dan fluktuasi nilai tukar yang akhirnya menurunkan daya beli masyarakat (Nirmalasari L., 2018). Perdagangan saham industri ini sepanjang tahun 2019 (yearto-date) mengalami kenaikan kinerja pangsa 
pasar sebesar 15,12\%, seperti pada tabel berikut:

Tabel 1. Indeks Kinerja Sektor Jasa di BEI Tahun 2019

\begin{tabular}{lc}
\hline \multicolumn{1}{c}{ Sektor } & $\begin{array}{c}\text { Kinerja Saham } \\
\text { (\%) }\end{array}$ \\
\hline $\begin{array}{l}\text { Properti, Real Estate dan } \\
\text { Konstruksi Bangunan }\end{array}$ & 15,12 \\
Infrastruktur, Utilitas, dan & 13,99 \\
$\begin{array}{l}\text { Transportasi } \\
\text { Keuangan }\end{array}$ & 9,19 \\
$\begin{array}{l}\text { Perdagangan, Jasa, dan } \\
\text { Investasi }\end{array}$ & 2,59 \\
\hline
\end{tabular}

Sumber: BEI, (www.market.bisnis.com, diakses 27 Januari 2020)

Kinerja saham industri yang tinggi adalah bentuk ketertarikan investasi yang tinggi oleh investor di pasar modal, realitas dari ketertarikan tersebut dinyatakan dengan harga saham perusahaan. Harga saham dijelaskan sebagai nilai dari sertifikat kepemilikan yang mencerminkan kekayaan perusahaan. Perubahan dan fluktuasi di dalamnya bergantung pada kondisi demand yang apabila tinggi maka harga saham bergerak naik. Sebaliknya, jika suppy rendah maka harga saham dapat bergerak turun (Putri, LP, 2017).

Analisi pada harga saham sangat penting karena terkait dengan keuntungan dan atau kerugian yang diperoleh, namun, tren saham sulit diprediksi secara langsung, karena fluktuasi harga saham memiliki banyak anteseden diantaranya, suku bunga, inflasi, kinerja perusahaan, dan lainnya (Bagya et al., 2016).

Pada beberapa literature dalam menganalisis harga saham diproksikan dengan harga penutupan. transaksi saham (closing price) yaitu harga penutupan pasar saham tahunan yang digunakan oleh pembeli dan penjual pada saat berakhirnya bursa perdagangan (Lilianti, 2018). Fakta empiris menunjukkan bahwa di antara 82 emiten, diantaranya terdapat 10 emiten yang sangat popular dikalangan investor, untuk itu dapat dilihat pada tabel berikut:
Tabel 2. Harga Saham Sektor Properti, Real Estate dan Konstruksi Bangunan

\begin{tabular}{cccc}
\hline $\begin{array}{c}\text { Kode } \\
\text { Emiten }\end{array}$ & \multicolumn{3}{c}{ Harga Saham (Closing Price) } \\
& 2016 & 2017 & Perubahan \\
\hline ACST & 2.820 & 2.460 & -360 \\
ADHI & 2.080 & 1.885 & -195 \\
GMTD & 6.950 & 10.175 & 3.225 \\
IDPR & 1.120 & 1.050 & -70 \\
LPKR & 720 & 488 & -232 \\
PPRO & 340 & 189 & -151 \\
PWON & 565 & 685 & 120 \\
RDTX & 10.000 & 6.000 & -4.000 \\
WIKA & 2.360 & 1.550 & -810 \\
WSKT & 2.550 & 2.210 & -340 \\
\hline
\end{tabular}

Sumber: $w$ ww.idx.co.id (data diolah dan diunduh pada 20 Januari 2020)

Data pada table 2 menunjukkan bahwa dari 10 (sepuluh) terdapat 2 (dua) emiten yang harga sahamnya mengalami peningkatan pada tahun 2016 - 2017 yaitu GMTD sebesar Rp 3.225 dan PWON sebesar Rp 120, terdapat 8 (delapan) emiten lainnya yang kinerja saham menurun tahun 2016-2017. Nilai penurunan dan peningkatan harga saham pada beberapa perusahaan sangat bervariasi yang disebabkan oleh beberapa faktor seperti laba per saham dan dividen per saham yang merupakan determinan harga saham penutupan.

Harga saham dalam literatur keuangan dipengaruhi tiga faktor, faktor internal, eksternal, dan teknikal. Diantara ketiga faktor tersebut terdapat faktor yang sangat kuat yaitu faktor internal perusahaan yang ditunjukkan melalui publikasi laporan keuangan, peramalan laba sebelum akhir tahun fiskal dan setelah akhir tahun fiskal, earning per share (EPS), dividen per share (DPS), price earning ratio, net profit 
margin, return on assets (Fatmawatie, A. S., dan Hamid, M., 2018).

Laba per saham merupakan kontribusi laba yang diberikan kepada pemegang saham dibandingkan dengan jumlah saham yang diperdagangkan. Rasio ini digunakan untuk mengukur keberhasilan manajemen dalam mencapai keuntungan bagi pemegang saham. Oleh karena itu, dengan mengetahui laba per saham, investor dapat menilai potensi laba yang akan diterimanya (Imelda Khairani, 2016).

Laba per saham (Earning per share) menunjukkan laba untuk setiap lembar saham. Naik atau turunnya laba perlembar saham dari tahun ke tahun menjadi issue penting dalam mengetahui tinggi ataupun rendahnya kinerja manajemen. Perusahaan dapat memberikan keuntungan yang tinggi kepada pemegang saham ditandai dengan tingginya laba perlembar saham, sebaliknya jika laba perlembar saham yang dihasilkan lebih rendah, maka perusahaan dapat memberikan tingkat keuntungan yang rendah pula (Rahmadewi, P. W., dan Abundanti, N., 2018).

Fakta empiris memberikan bukti terdapat kontribusi yang bermakna antara laba per saham dengan harga saham (Retni Noviasari, 2013; Bagya dkk., 2016). Hasil berbeda ditemukan pada peneliti lainnya, laba per saham tidak dapat berkonstribusi dalam meningkatkan harga saham (Anita dan Pavitra, 2014; Imelda Khairani, 2016).

Anteseden lainnya yang dominan meningkatkan harga saham adalah dividen yang merupakan pembagian keuntungan secara proporsional dari perusahaan kepada pemilik, yang dibagikan salah satunya dalam bentuk dividen per saham. Dividen per saham merupakan rasio mengukur jumlah dividen yang dibagikan dibanding dengan jumlah saham beredar pada periode tahun tertentu. Rasio ini menggambarkan bahagian laba yang dibagikan dalam bentuk dividen kepada pemegang saham sesuai dengan jumlah lembar saham yang dimiliki (Maulana, F., 2017).

Dividen per saham adalah keuntungan yang dibagikan secara proporsional kepada pemegang saham berdasarkan jumlah lembar kepemilikan saham. Informasi dividen per saham sangat penting untuk mengetahui berapa besar keuntungan setiap lembar saham yang akan diberikan kepada pemegang saham. Jika dividen per saham yang akan diberikan tinggi, maka akan memicu peningkatan harga. Tingginya dividen per saham akan memotivasi investor untuk membeli saham perusahaan tersebut. Banyaknya saham yang dibeli mendorong meningkatkan harga saham (Harpono, F. F., dan Chandra, T., 2019).

Penelitian Retni Noviasari (2013) membuktikan jika dividen per saham berkontribusi signifikan pada harga saham. Fakta tersebut memperoleh bantahan dari peneliti lainnya, bahwa dividen per saham berkontribusi negatif pada harga saham (Imelda Khairani, 2016).

Keterkaitan antara laba per saham dan dividen per saham dalam menjelaskan harga saham ditunjukkan melalui teori sinyal yang menekankan pentingnya informasi yang dikeluarkan perusahaan sangat ditekankan dalam mempengaruhi keputusan investasi eksternal perusahaan. Informasi merupakan aspek inti bagi investor, informasi yang diperoleh didalmnya terdapat keterangan ataupun gambaran untuk keadaan masa lalu, saat ini maupun masa mendatang atas survive atau tidaknya perusahaan. Penyajian informasi yang transfaran sangat diperlukan investor sebagai pendukung keputusan investasi. Informasi yang terkait dengan laba per saham (earning per share) ataupun pembagian dividen per saham (dividen per share) merupakan hal yang menarik perhatian investor (Maulana, F., 2017; Harris, dkk., 2020; Lorenza, dkk., 2020).

Laporan keuangan perusahaan digunakan oleh investor untuk memprediksi masa yang akan datang. Sinyal pergerakan laba per saham (earning per share) dan dividen per saham (dividen per share) dapat dilihat dari reaksi harga saham. Peningkatan laba per saham (earning per share) dan dividen per saham (dividen per share) mengakibatkan pelaku perdagangan saham akan bereaksi tinggi, jika pelaku perdagangan berestimasi terjadi kondisi yang diharapkan atas laba per saham (earning per share) dan dividen per saham (dividen per share), maka 
beranggapan bahwa terdapat prospek yang baik di masa mendatang, demikian juga sebaliknya.

Terdapatnya penurunan dan peningkatan pada harga saham perusahaan serta adanya perbedaan hasil temuan dari beberapa peneliti terdahulu menjadi alasan dilakukannya studi ini, sehingga tujuan dari studi ini untuk menguji dampak Earning Per Share (EPS) dan Dividen Per share (DPS) terhadap harga saham, serta membandingkan diantara kedua variabel tersebut untuk mengetahui kontribusi dominannya

\section{METODE PENELITIAN}

Penelitian ini menggunakan pendekatan kuantitatif yaitu menggunakan cara berpikir deduktif. Jika dilihat dari tingkat eksplanasinya, penelitian ini tergolong penelitian asosiatif. Penelitian asosiatif adalah penelitian yang bertujuan mengetahui pengaruh atau hubungan sebab akibat, yaitu variabel bebas atau independen terhadap variabel terikat atau dependen (Prawiroharjo Thauwrisan, L., 2016).

Populasi penelitian ini sebanyak 82 emiten. Teknik purposive sampling digunakan dalam penarikan sampel penelitian ini, sehingga hasilnya terdapat sebanyak 16 perusahaan yang memenuhi kriteria.

Penelitian menggunakan bentuk pengumpulan data atau desain cross-sectional, yang merupakan suatu jenis penelitian yang dilakukan dengan cara mengumpulkan data pada satu waktu yang sama selama satu periode hari, minggu atau bulan maupun tahun (Susanto, 2013:67). Dengan jenis data yang digunakan adalah jenis data kuantitatif. Data yang dimaksud dalam penelitian ini adalah laba per saham (earning per share), dividen per saham (dividen per share) dan harga saham penutupan. Data sekunder digunakan sebagai sumber data yang diperoleh Laporan keuangan publikasi BEI periode 2016-2018. Pengumpulan data dilakukan melalui dokumentasi.

\section{HASIL DAN PEMBAHASAN}

\section{Uji Asumsi Klasik}

Uji Kenormalan data, bertujuan untuk menguji apakah dalam model regresi variabel independen dan dependen memiliki distribusi data normal atau tidak (Ghozali, 2016:154). Model regresi yang baik memiliki distribusi normal atau mendekati normal. Uji normalitas data dapat dilakukan menggunakan One Sample Kolmogorov- Smirnov dengan persyaratan apabila $p$-value $>0,05$, maka data terdistribusi normal. Sedangkan, jika hasil One Sample Kolmogorov-Smirnov menunjukkan nilai p-value $<0,05$, maka data tidak terdistribusi normal.

Tabel 3. Hasil Uji Normalitas

\begin{tabular}{cc}
\hline Pengukur & Unstandardized Residual \\
\hline Banyaknya Data & 48 \\
Nilai t-statistik & 0.095 \\
p-value & 0.200 \\
\hline
\end{tabular}

Berdasarkan data output SPSS diatas, dapat diketahui bahwa nilai test statistic sebesar 0.095 $>0.05$ dan nilai Kolmogorov-Smirnov (KS) 0.200 $>0.05$, maka dapat dinyatakan bahwa data yang diuji berdistribusi normal.

Uji Durbin-Watson, bertujuan untuk melihat apakah terdapat hubungan antara error-term pada waktu pengamatan berjalan dengan waktu pengamatan data sebelumnya dalam persamaan regresi linear (Ghozali, 2016 : 155).

Hasil uji DW pada model summary menunjukkan bahwa nilai Durbin-Watson sebesar 1.592, pembanding menggunakan nilai signifikan $5 \%$ (0.05). Jumlah sampel sebanyak 48 (n) dan 2 variabel bebas $(k=2)$, maka akan diperoleh nilai $\mathrm{dL}$ sebesar 1.4500 , dU sebesar 1.6231 pada tabel Durbin-Watson. Nilai DW 1.592 berada di daerah antara nilai $\mathrm{dL}$ dan nilai $\mathrm{dU}$ atau $\mathrm{dL}<\mathrm{d}<\mathrm{dU}$, maka yang terjadi tidak menghasilkan kesimpulan yang pasti (berada di daerah keraguraguan).

Uji Multikolonieritas. Model regresi yang dikatakan baik apabila tidak terjadi gangguan multikol. Ada atau tidaknya multikolonieritas di dalam persamaan regresi dapat dideteksi dan dilihat nilai Tolerance TOL dan VIF (Ghozali, 2016:103)..

Tabel 4. Hasil Uji Multikolonieritas

Independen Tolerance VIF




\begin{tabular}{lll}
\hline EPS & .732 & 1.365 \\
DPS & .732 & 1.365 \\
\hline
\end{tabular}

Hasil multikol-test menunjukkan nilai Tolerance variabel bebas $=0.732>0.10$ dan nilai VIF $=$ $1.365<10.00$, sehingga demikian dinyatakan bahwa data hasil pengujian tidak terjadi multikolonieritas.

Uji Keragaman data, befungsi untuk mengetahui apakah terjadi ketidaksamaan varian dari residual satu pengamatan ke pengamatan lain dalam model regresi. Apabila varian dari residual dari satu pengamatan ke pengamatan yang lain tetap (homogen) demikian juga sebaliknya. Hasil yang baik jika tidak terjadi hetero (Ghozali, 2016:134).

Tabel 5. Test Keragaman Data

\begin{tabular}{ccr}
\hline Independen & t-statistik & p-value \\
\hline EPS & .221 & .826 \\
DPS & .374 & .710 \\
\hline
\end{tabular}

Hasil pengujian tabel diatas, membuktikan bahwa nilai $p$-value pada EPS sebesar $0.826>$ 0.05 dan DPS sebesar $0.710>0.05$, sehingga hasil tersebut mengindikasikan bahwa tidak terjadi data yang beragam (hetero).

Pengujian Linearitas Kriteria uji ini yaitu dua variabel dikatakan mempunyai hubungan yang linear apabila signifikasi (linearity) $<0,05$ (Ghozali, 2016:105)..

\section{Gambar 1. Linearitas Earning Per Share Terhadap Harga Saham}

Hasil Scatterplot diatas, menunjukkan bahwa adanya hubungan linear antara laba per saham terhadap harga saham (linearitas $=0.530$ ).

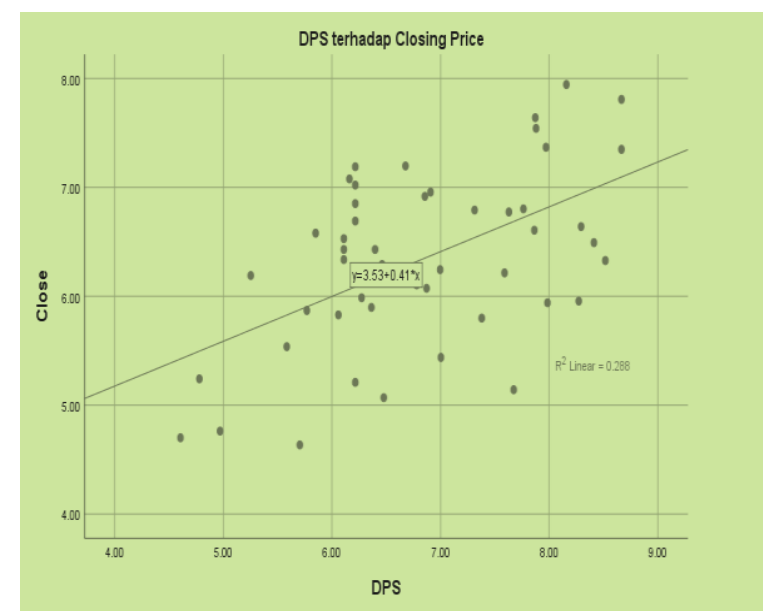

Gambar 2. Linearitas Dividen Per Share Terhadap Harga Saham

Scatterplot pada Gambar 2. diatas, menunjukkan bahwa terdapat linearitas antara dividen per saham dengan harga saham (linearitas $=0.288$ ).

\section{Analisis Statistik Deskriptif}

Deskriptif statistik memberikan penjelasan singkat pada data sehingga menjadi suatu informasi yang lebih jelas dan dapat dengan mudah dipahami (Ghozali, 2016:19).

Tabel 6. Statistik Deskriptif

\begin{tabular}{crr}
\hline Pengamatan & \multicolumn{1}{c}{ Mean } & \multicolumn{1}{c}{$\begin{array}{c}\text { Standar } \\
\text { deviasi }\end{array}$} \\
\hline Close & 6.34 & 0,81 \\
EPS & 8.31 & 0,86 \\
DPS & 6.83 & 1,06 \\
\hline
\end{tabular}

Tabel 6 memberikan bukti bahwa sebanyak 48 data dalam penelitian ini digunakan sebagai sampel (N), secara terperinci data statistik deskriptif pada variabel pengamatan mencoba mengkomparasi nilai rata-rata (mean) dengan standar deviasi.

Pada variabel closing price nilai mean $=6.3421,>$ nilai std.dev $=0.81292$. Nilai (mean) yang lebih besar ini menunjukkan jika data variabel yang digunakan adalah baik.

Mean untuk EPS $=8.3108>$ nilai std. dev. $=$ 0.86303 . Maka nilai rata-rata (mean) yang lebih besar ini dapat dinyatakan bahwa terjadi peningkatan nilai, bahwa EPS dapat memengaruhi dependen variabel. 
Mean pada variabel DPS $=6.8353>$, std. dev. $=$ 1.06061. Hal ini dapat dinyatakan bahwa DPS dapat memengaruhi dependen variabel.

\section{Multiple regression}

Penentuan terdapat ataupun tidaknya pengaruh yang positif signifikan ataupun sebaliknya, dapat dilihat pada nilai t-hitung dan $p$-value, untuk itu hasilnya dapat ditunjukkan sebagai berikut:

Tabel 7. Hasil Uji Regresi Linear Berganda

\begin{tabular}{ccrr}
\hline \multirow{2}{*}{ Model } & \multicolumn{2}{c}{ Nilai Koefisien } & \\
& Unstandardized & t-statistik \\
& Beta & St. error & \\
\hline (Constant) & .384 & .786 & .489 \\
EPS & .579 & .108 & 5.348 \\
DPS & .168 & .088 & 1.906 \\
\hline
\end{tabular}

$\mathrm{Y}_{(\text {H.saham })}=0.384_{(\text {Kons. })}+0.579_{(\mathrm{EPS})}+0.168_{(\mathrm{DPS})}+$ $0.786_{(\mathrm{e})}$

Sehingga dapat dijelaskan sebagai berikut :

1) Nilai peubah tetap sebesar 0.384 menyatakan jika EPS $\left(\mathrm{X}_{1}\right)$ dan DPS $\left(\mathrm{X}_{2}\right)$ nilainya 0 , maka $C P(Y)$ nilainya sebesar 0.384 .

2) Koefisien EPS sebesar 0.579 menyatakan bahwa setiap penambahan 1\% EPS, maka akan meningkatkan $C P$ sebesar 0.579 pada saat variabel lainnya tidak berubah (konstan).

3) Koefisien DPS sebesar 0.168 menyatakan bahwa setiap penambahan $1 \%$ DPS, maka akan meningkatkan $C P$ sebesar 0.168 pada saat variabel lainnya tidak berubah (konstan).

\section{Uji Pemodelan Regresi} Uji kesesuain ( Uji $F$ )

Tabel 8. Fisher Test

\begin{tabular}{ccc}
\hline Model & F-test & p-value \\
\hline Regression & 29.200 & $.000^{\mathrm{b}}$ \\
\hline
\end{tabular}

Penentuan nilai F-tabel merujuk pada nilai df1 dan df2 yang berdasarkan pada tabel diatas, maka nilai df1 dan df2 yaitu 2 dan 45 . Hal ini dapat dilakukan menggunakan bantuan MSExcel dengan formulasi $\mathrm{FINV}=(0.05,2,45)$, maka nilai F-tabel diperoleh yaitu 3.204317. Maka berdasarkan perolehan hasil menggunakan formulasi F-INV, disimpulkan nilai F-hitung $>$ Ftabel $(29.200>3.204317)$ dan nilai $p$-value $=<$
0.05 , maka model yang diuji memenuhi kriteria kelayakan model.

\section{Uji Pemodelan ( Uji $t$ )}

Tabel 9. Student test

\begin{tabular}{crr}
\hline Model & t-statistik & \multicolumn{1}{l}{ p-value } \\
\hline (Constant) & .489 & .627 \\
EPS & 5.348 & .000 \\
DPS & 1.906 & .063 \\
\hline
\end{tabular}

Penentuan t-tabel merujuk pada $\mathrm{df}=(\mathrm{n}-\mathrm{k}-1)$ sehingga diperoleh besar df sebesar $45=(48-2-1)$. Penghitungan ini dilakukan menggunakan MSExcel melalui formulasi TINV $=(0.05,45)$, sehingga diperoleh nilai t-tabel sebesar 2.014.

\section{Uji Kontribusi $\left(R^{2}\right)$ \\ Tabel 10. Koefisien Determinasi $\left(R^{2}\right)$}

$$
\text { R R Square }
$$

$.752^{\mathrm{a}}$

.565

Hasil tabel 10., menunjukkan nilai uji koefisien determinasi $\left(R^{2}\right)$ sebesar 0.565 yang berarti menunjukkan pengaruh antar variabel independen yaitu EPS dan DPS terhadap variabel dependen yaitu harga saham sebesar $56.5 \%$. Hal ini mengartikan harga saham ( $Y$ ) dapat dipengaruhi oleh EPS $\left(X_{1}\right)$ dan DPS $\left(X_{2}\right)$, sedangkan sisanya $43.5 \%$ dipengaruhi oleh faktor-faktor lain yang tidak dijelaskan dalam penelitian ini.

\section{1) Laba Per Saham (EPS) Pada Harga Saham}

Hasil uji t variabel EPS pada CP diperoleh tstatistik $=5.348$ dengan $p$-value $=0.000$. Nilai signifikan lebih kecil dari $p$-value 0.05 atau 0.000 $<0.05$, maka $\mathrm{H}_{1}$ dinyatakan terdukung dan $\mathrm{H}_{0}$ dinyatakan menolak. Variabel EPS menunjukkan t-statistik $=5.348$ dengan $\mathrm{t}$-tabel $=2.014$, maka nilai t-hitung $>$ t-tabel $(5.348>2.014)$ sehingga EPS dinyatakan memberikan kontribusi terhadap harga saham, bahwa EPS dinyatakan memiliki kontribusi signifikan terhadap harga saham.

Temuan penelitian ini sesuai dengan penelitian yang dilakukan Bagya dkk. (2016), bahwa EPS (laba per saham) yang tinggi mengakibatkan tingginya CP. Artinya semakin tinggi kemampuan perusahaan membagikan laba 
kepada investor, maka mendorong pergerakan harga saham perusahaan semakin meningkat.

\section{2) Dividen Per Saham (DPS) pada Harga Saham}

Uji t-statistik pada variabel DPS terhadap harga saham diperoleh nilai t-statistik $=1.906$ pada level $p$-value $=0.063$. Nilai $p$-value $0.063>0.05$, maka studi ini menolak $\mathrm{H}_{1}$ dan menerima $\mathrm{H}_{0}$. Variabel DPS mempunyai t-statistik $=1.906<\mathrm{t}$ tabel $=2.014$, sehingga pengujian membuktikan DPS memiliki kontribusi positif dan tidak signifikan terhadap harga saham. Hasil penelitian ini berbeda dengan temuan Imelda Khairani (2016), bahwa dividen per saham berkontribusi negatif dan tidak signifikan terhadap harga saham.

\section{SIMPULAN}

Berdasarkan hasil penelitian dan pembahasan, maka peneliti dapat memberikan kesimpulan bahwa :

1. Pergerakan Laba per saham (EPS) berkontribusi positif dan signifikan pada harga saham CP. Hal ini dapat dilihat dari hasil pengujian uji $\mathrm{t}$ variabel EPS terhadap harga saham yang diperoleh nilai t-hitung sebesar 5.348 dan nilai signifikan sebesar 0.000 .

2. Dividen per saham (Dividen per share) memberikan pengaruh positif dan tidak signifikan terhadap harga saham perusahaan sektor properti, real estate dan konstruksi yang terdaftar di Bursa Efek Indonesia. Hal ini dapat dilihat dari hasil pengujian uji $t$ variabel DPS terhadap harga saham yang diperoleh nilai t-hitung sebesar 1.906 dan nilai signifikan sebesar 0.063 .

3. Laba per saham (earning per share) merupakan independen variabel yang ominan terhadap harga saham perusahaan sektor properti, real estate dan konstruksi yang terdaftar di Bursa Efek Indonesia dengan total nilai kontribusi sebesar $44.77 \%$.

\section{DAFTAR PUSTAKA}

1. Bagya, M. B., Suhadak, S., \& Handayani, S. R. (2016). Pengaruh Earning Per Share (EPS), Return On Equity (ROE), Dan Price Earning Ratio (PER) Terhadap Harga Saham (Studi Pada Perusahaan Telekomunikasi Yang Terdaftar Di Bursa
Efek Indonesia Periode Tahun 20102014). Jurnal Administrasi Bisnis, 41(1), 100-107.

2. Fatmawatie, A. S., \& Hamid, M. (2018). Pengaruh Earning Per Share (EPS) Dan Deviden Per Share (DPS) Terhadap Harga Saham Indeks LQ-45 Di Bursa Efek Indonesia Periode 20122016. Doctoral Dissertation, STIE Widya Wiwaha.

3. Ghozali, Imam. 2016. Aplikasi Analisis Multivariete dengan Program IBM SPSS 23 (Edisi 8). Cetakan Ke VIII. Semarang: Badan Penerbit Universitas Diponegoro.

4. Harpono, F. F., \& Chandra, T. (2019). Analisis Pengaruh DER, ROE, PER, EPS, Dan DPS Terhadap Harga Saham Pada Perusahaan Sub Sektor Kesehatan Dan Farmasi Yang Terdaftar Di BEI Tahun 2010-2017. Bilancia: Jurnal IImiah Akuntansi, 3(1),69-78.

5. Harris, M. I., Sjahruddin, H., \& Themba, O. S. (2020). Kontribusi Rasio Aktivitas dan Ukuran Perusahaan pada Rentabilitas PT. Telekomunikasi Indonesia (Persero), Tbk. Jurnal SEKURITAS (Saham, Ekonomi, Keuangan dan Investasi, 3(3), 219-229.

6. Khairani, I. (2016). Pengaruh Earning Per Share (EPS) Dan Deviden Per Share Terhadap Harga Saham Perusahaan Pertambangan Yang Terdaftar Di Bursa Efek Indonesia (Bei) Tahun 20112013. Jurnal Manajemen Dan Keuangan, 5(2), 566-572

7. Lilianti, E. (2018). Pengaruh Dividend Per Share (DPS) Dan Earning Per Share (EPS) Terhadap Harga Saham Pada Perusahaan Sub Sektor Farmasi Di Bursa Efek Indonesia. Jurnal Ecoment Global; Kajian Bisnis Dan Manajemen, 3(1), 12-22.

8. Lorenza, D., Kadir, M. A., \& Sjahruddin, H. (2020). Pengaruh Struktur Modal Dan Ukuran Perusahaan Terhadap Profitabilitas Pada Perusahaan Otomotif Yang Terdaftar Di Bei. Jurnal Ekonomi Manajemen, 6(1), 13-20.

9. Maulana, F. (2017). Pengaruh FaktorFaktor Fundamental Terhadap Harga Saham (Studi Kasus Pada Perusahaan Manufaktur Sub Sektor Makanan Dan 
Minuman Yang Terdaftar Di Bursa Efek Indoneisa (BEI) Periode 2013-2015). Doctoral Dissertation, IIB Darmajaya.

10. Nirmalasari, L. (2018). Analisis Financial Distress Pada Perusahaan Sektor Property, Real Estate Dan Konstruksi Bangunan Yang Terdaftar Di Bursa Efek Indonesia. Jurnal Manajemen Bisnis Indonesia (Jmbi), 7(1), 46-61.

11. Noviasari, R. (2013). Pengaruh Dividend Per Share (DPS) Dan Earning Per Share (EPS) Terhadap Harga Saham Pada Perusahaan Manufaktur Yang Terdaftar Di Bursa Efek Indonesia. Doctoral Dissertation, Universitas Islam Negeri Sultan Syarif Kasim Riau.

12. PrawiroharjoThauwrisan, L. I. D. Y. A. (2016). Faktor-Faktor

Yang
Mempengaruhi Kebijakan Dividen Terhadap Harga Saham Perusahaan Sektor Properti, Real Estate, Dan Konstruksi Bangunan Yang Terdaftar Di Bursa Efek Indonesia. Doctoral Dissertation.

13. Putri, L. P. (2017). Pengaruh Profitabilitas Terhadap Harga Saham Pada Perusahaan Pertambangan Batubara Di Indonesia. Jurnal IImiah Manajemen Dan Bisnis, 16(2).

14. Rahmadewi, P. W., \&Abundanti, N. (2018). Pengaruh EPS, PER, CR Dan ROE Terhadap Harga Saham Di Bursa Efek Indonesia. E-Jurnal Manajemen, 7(4), 2106-2133 